\title{
Student Perceptions of Metacognitive Strategy Use in Lecture Listening Comprehension
}

\author{
Suzanah Selamat \\ Islamic Science University, Malaysia \\ Gurnam Kaur Sidhu \\ Universiti Teknologi MARA, Malaysia
}

\begin{abstract}
Listening to lectures is difficult, especially for students who have just entered university. It is even more daunting for ESL students attending lectures delivered in English. Various literatures have highlighted the importance of explicit training to improve students' academic listening skills (O'Malley \& Chamot, 1990; Oxford, 1996; Swan, 2011). This paper explores ESL students' perceptions towards a Metacognitive Strategy Instruction (MetSI) programme to improve their lecture listening comprehension abilities. The study involved 34 first-year students from the Faculty of Education in a public university in Malaysia. Instrumentation for the study involved the use of a questionnaire and semi-structured interviews. Data revealed that the students perceived the MetSI training as helpful in improving their lecture listening skills and in enabling them to be more effective in extracting information from lectures. Findings from the study suggest the need for students to play a more active role in overcoming their listening difficulties.
\end{abstract}

In recent years, there has been increasing interest and research on the need for effective listening skills and strategies for ESL university students studying in English-medium institutions (Hyon, 1997). This is because English has become a major language in tertiary education and the language of university lectures (Long \& Richards, 1994). Many tertiary institutions in Malaysia use English as the medium of instruction in recognition to the fact that English has become the lingua franca of the borderless community.

Researchers point out that listening to lectures is a major part of university study (Benson, 1994; Morell, 2004; Richards, 1983) and this is highlighted by Benson (1994) who describes the lecture as "the central ritual" (p.181) of university culture. A study by Ferris \& Tagg (1995, cited in Hyon, 1997) demonstrated that the lecture is the most common mode of instruction at over 230 university and college faculties. Hence, effective listening comprehension skills are essential for students' academic success (Benson, 1994; Dunkel, 1991; Flowerdew, 1994; Vandergrift, 2004). However, during lectures in English, ESL students are faced with greater difficulties than native speakers because ESL students have to comprehend subject matter delivered in English as well as contend with other obstacles that a lecture could create, such as

Language Education in Asia, 2011, 2(2), 185-198. http://dx.doi.org/10.5746/LEiA/11/V2/I2/A02/Selamat_Sidhu 
understanding the lecturer's accent, and speed of delivery. ESL students also have to contend with the difficulty of listening and taking notes at the same time, as well as processing visual aids such as presentation slides or textbooks. This leads to comprehension difficulties when ESL students listen to academic lectures.

Mendelsohn (2002) argues that many ESL students' listening skills are not developed enough to enable them to effectively extract content information from university lectures. In fact, lecturers often assume that students develop their listening skills through "osmosis and without help" (Mendelsohn, 1984, as cited in Oxford, 1993, p. 205). This corroborates the findings of a study analysing problems faced by undergraduate students in Malaysia by Aziz \& Ismail (2005): ESL students lack the necessary skills to learn through lectures given in English. Experts believe that one of the ways to develop students' listening skills is through extensive training (O'Malley \& Chamot, 1990; Oxford, 1996; Swan, 2011).

Although listening has been taught in many language programmes, experts still believe that much research needs to be done to enable a more effective classroom teaching of the skill (Anderson \& Lynch, 1988; Buck, 1995; Goh, 2000; Mendelsohn, 1998; Vandergrift, 2004). New approaches to teaching listening have emerged in recent years due to developments in the field of cognitive psychology (Flowerdew \& Miller, 2005; Goh, 2008; Lynch, 1998; Macaro, Graham, \& Vanderplank, 2007; Rubin, 1994). Within this field, the metacognitive approach has become a more popular research topic (Chamot, 1995; Goh, 2008; Mendelsohn, 1995, 1998; Vandergrift, 2004). One of the metacognitive approaches is training learners to apply effective strategies to cope with the demands of listening (Mendelsohn, 1998).

Evidence from research on reading and writing highlights the fact that metacognitive strategies assist students in managing their learning more effectively. They are able to maximise the information received to improve their performance of required tasks. Wenden (1998) argues that learners who use their metacognitive abilities seem to have the following advantages:

1. They are more strategic learners.

2. Their rate of progress in learning as well as the quality and speed of their cognitive engagement is faster.

3. They are confident in their abilities to learn.

4. They do not hesitate to obtain help from peers, teachers, or family when needed.

5. They provide accurate assessments of why they are successful learners.

6. They think clearly about inaccuracies when failure occurs during an activity.

7. Their tactics match the learning task and adjustments are made to reflect changing circumstances.

8. They perceive themselves as continual learners and can successfully cope with new situations.

(adapted from Wenden, 1998)

In his study, Vandergrift (2004) employed a technique called metacognitive sequence to facilitate his subjects' use of metacognitive strategies during listening. The results of the study show that these processes benefit the subjects through raising their awareness of the use of 
strategy and providing a kind of scaffolding as the subjects go through listening tasks. Vandergrift's study seems to advocate the use of these strategies to improve learners' comprehension as well as to motivate them to learn.

The present study examines beginning university students' perceptions towards a Metacognitive Strategy Instruction (MetSI) programme and its effects on their lecture listening comprehension.

\section{Methodology}

Data for the study were obtained from a questionnaire and semi-structured interviews with the subjects. The subjects were 34 first-semester students undertaking a Bachelor of Education (B.Ed) at a public Malaysian university. They were from non-English speaking backgrounds and English was a second or foreign language to them. Prior to entering university, most of their communications in English was limited to English lessons in their schools only. First-year students were chosen because they face greater challenges in understanding lectures as most schools in Malaysia still adopt the traditional teacher-centred learning style and are examoriented in nature. In general, the subjects found listening comprehension in an academic English environment rather challenging.

The subjects were 22 females and 11 males in their 20s and one female student who was 42 years old. All the students in this study had enrolled in courses in the Faculty of Education. Ten $(29.4 \%)$ students were enrolled in the B.Ed in Chemistry course while another ten $(29.4 \%)$ were from the B.Ed TESL programme. Nine (26.5\%) students were enrolled in the B.Ed in Physics programme and five (14.7\%) students were in the B.Ed in Biology programme.

\section{Instruments}

Questionnaire. Prior to the 10-week Metacognitive Strategy Instruction (MetSI) programme, the students were asked to answer a questionnaire on metacognitive lecture listening strategies. The questionnaire was adapted from the Metacognitive Awareness Listening Questionnaire (MALQ) by Vandergrift, Goh, Mareschal, and Tafaghodtari (2006). The MALQ has been used in other research as a tool to raise students' awareness of listening processes and to increase the self-regulated use of comprehension strategies (Coşkun, 2010). The questionnaire items are related to five metacognitive factors associated with listening strategies; however, for this study, only four items are discussed: (a) the subjects' personal knowledge on listening, (b) planningevaluation metacognitive strategies, (c) directed attention strategies, and (d) problem-solving strategies. The questionnaire responses were analysed according to these factors using frequency counts.

Semi-structured interview. At the end of the 10-week strategy training, ten out of the 34 students were randomly selected and interviewed about their experiences in learning the new strategies. In particular, the semi-structured interviews were conducted to gain insights into their perceptions regarding the MetSI training that they had undergone (see Appendix A).

\section{Treatment}

Metacognitive Strategy Training Instruction (MetSI) is a 10-week intensive metacognitive listening strategy module aimed at improving students' lecture listening skills and metacognitive strategies. Each lesson consisted of listening tasks where students listened to numerous listening texts, followed by comprehension activities. Each teaching module presented was divided into specific underlying strategies that students would have 
opportunities to discuss and practice. The following were some of the metacognitive strategies taught during the MetSI programme:

- summarising

- comprehension monitoring

- planning

- task knowledge

- self and peer evaluation

- directed attention

- problem identification

Integrated within these strategies were activities including lecture wrap-ups, KWL charts (adapted from Ogle, 1986; see Appendix B), metacognitive listening sequence (adapted from Vandergrift, 2003; see Appendix C), and self-questioning strategies.

The lessons included three principal stages: pre-listening, listening, and post-listening. In the pre-listening stage, students were provided with pre-listening questions for discussion. The pre-listening activities included revision and presentation of language items as well as planning and preparation for the activity to be undertaken in the next stage. At the listening stage, students did activities or tasks aimed at practicing the strategies and developing skills. Each lesson consisted of a quick review, including a dialogue or other types of audio exercises. When introducing a new strategy, the instructor included demonstrations and examples so that students would view the strategy in action. The instructor also asked questions. Finally, at the post-listening stage, students were given tasks for strategy practice. They had further practice to consolidate, extend, and review the strategies, either in a different context or to produce an outcome such as completing worksheets or a summary.

At each stage, prompting, questioning, and modelling techniques and strategies were consistently employed by the instructor to increase students' awareness. This was done to demonstrate, discuss learning, and help students to reflect on what they had done, how they did it, and how well they had performed. This is in accordance with Wenden's (1985) suggestion that instructors need to expand their role by taking on a guiding, questioning role which involves informing students about language learning, what they are doing, and how they are going to do it.

\section{Results}

The questionnaire items were analysed according to metacognitive factors that are related to listening strategies suggested by Vandergrift et al. (2006), as previously mentioned.

\section{Personal Knowledge}

Wenden (1991, cited in Vandergrift, 2002) states that one type of metacognitive knowledge is personal knowledge, which refers to knowledge of the cognitive and affective factors that facilitate learning and what learners know about themselves as learners.

Pre-treatment questionnaire. Analysis of the questionnaire revealed that $47 \%$ of the students found listening to be the most difficult language skill compared to reading, writing, and speaking. A majority of the subjects (65\%) also viewed listening as challenging. 
These findings were further elaborated on by respondents during the interview sessions. The interviews, however, revealed that some students found speaking more difficult than listening because they felt that they were being judged whenever they spoke in English. On the other hand, due to the receptive nature of the listening process, the students did not feel that they were being judged by their listening abilities:

Speaking is most difficult because sometimes when we speak in English, we think in English right, to come up with the words in English is quite difficult. (S5)

Post-treatment interviews. Interviews also revealed that many students did not feel that listening skills in English were important for them to excel in schools as their English teachers often emphasised reading comprehension skills in the classrooms.

In my school, teachers always stressed on reading - not so much listening. They just did drilling in class . . . until we had to do MUET [Malaysian University Entrance Test], then we did listening. They also focussed on grammar, no listening ... (S1)

I've never learned how to listen. In schools, the teachers didn't teach us listening [skills]. (S3)

However, the interviews also revealed that the subjects' perceptions changed when they entered university, as they were faced with difficulties in understanding lectures delivered in English.

... in class, my friends and I were left behind because it was hard for us to understand and it was also hard for the lecturers to finish the syllabus ... The lecturers needed to clarify everything to make us understand, so we had a difficult time [completing the syllabus]. (S1)

I found it so difficult because I didn't practice listening English with my friend [in school] . . . I think we should include it [teach listening] in school because it helps a lot . . . because in Malaysia they [schools] don't teach listening . . . I think it is important because it is one of the skills to help learning in the university. (S3)

The above findings corroborate other research findings that language learners do not view strategies as important in listening skills and most language learners lack awareness that these strategies could positively affect their listening processes (Cohen \& Allison, 2000; Coşkun, 2010; Oxford, 1990; Vandergrift et al., 2006).

The findings of the interviews revealed that the students viewed the MetSI training as helpful in improving their lecture listening skills.

Yes, I feel the training is good for me because now I can understand the lecturers better. (S3)

The training was good for me because now I feel more confident now. (S7) 
I wish I had learned the strategies in school ... (S2)

All ten students interviewed felt that the training had helped them to extract information from lectures more effectively.

When I use the KWL sheet, I find it easier to understand the lecture. It's also easy to note down the important point. (S1)

Now I use the summarising technique so I know the important point of the lectures... (S6)

\section{Planning-Evaluation Metacognitive Strategies}

Research has shown the benefits of preparing and reviewing topics learned in a lecture. Studies by Rost (1994) and Dunkel \& Davis (1994) demonstrate that prior knowledge could assist students in understanding their lessons more effectively. Similarly, a study by Flowerdew \& Miller (1992) demonstrates that students with background knowledge of the lecture topic were able to relate more effectively to the lecture content.

Pre-treatment questionnaire and post-treatment interview. Analysis of the questionnaire responses showed that in terms of planning and evaluation strategies, the students did not fully utilise these strategies to assist in their lecture comprehension.

According to the results, only $55 \%$ of the students planned ahead on how they were going to listen to a lecture. The post-treatment interviews corroborated this finding, as students commented prior to attending the MetSI programme that they were not aware of the importance of preparing for lectures. Many students also reported that they did not know and had never been taught how to prepare for lectures. In addition, the post-treatment interviews also revealed that before the training, students did not feel that they needed to read lecture notes or the textbook in preparation for a lecture.

$\mathrm{I}^{\prime} \mathrm{d}$ just go into the lecture room ... (S3)

I didn't prepare anything; I just go [to a lecture]. (S5)

Sometimes, I "googled" [the topic] before the lecture, but only sometimes . . . (S1)

Findings from the post-treatment interviews show that after attending the MetSI programme, the students were able to plan their lecture listening.

Before I go to lectures, I fill the first column of the KWL sheet ... [the KWL sheet] is helpful because I can guess what the lecturer is going to talk about and it's easier for me [to understand the lecture] if I know what the lecturer is going to talk .... (S1)

Results from the questionnaire also showed that $59 \%$ of the students claimed that after listening to a lecture, they reflected on how they had listened, and how they might listen differently next time. However, only $44 \%$ of the subjects said that they periodically asked themselves if they were satisfied with their level of comprehension throughout the lecture. 
Interviews with the subjects of their experiences prior to the training concurred with the above findings:

... I didn't think (about) how I had done [in a lecture]. (S2)

.. I I asked my friends if I didn't understand, sometimes I asked the lecturer but after [the lecture was over]. (S6)

I asked my friend after class if I didn't understand, but I didn't like to stop the lecture. But most of the time I forgot to ask my friend [after the lecture] . . . Sometimes, we needed to go to the next lecture. (S1)

The reason why, prior to the training, students did not reflect or check their comprehension could be because they were unaware of these strategies. However, the interviews showed that the MetSI training had a positive effect in developing the students' self and peer reflections.

Sometimes, at the end of the lectures, I asked the lecturers if the points were correct . . . before [the training], I didn't dare ask the lecturers. (S6)

After the lecture, I can exchange my KWL sheet with my friends and I will write down points that I've missed ... (S2)

\section{Directed Attention Strategies}

Students' ability to direct their attention to a subject matter is an essential strategy to enable comprehension, especially during long lectures. This is supported by Kaplan \& Berman (2010) who point out that both our "executive functioning" and self-regulation are important factors that enable us to consciously control our attention.

Pre-treatment questionnaire. Analysis of the questionnaire demonstrates that the students were able to utilise this strategy. However, the strategies were limited to forcing themselves to focus. When faced with the problem of understanding a lecture, the majority of the students $(80 \%)$ would simply focus harder on the text. On top of this, the majority of the students $(79 \%)$ said that they did not give up and stop listening when faced with comprehension difficulties during lectures. Meanwhile, when the students lost concentration during lectures, the majority $(73 \%)$ stated that they recovered their concentration right away.

Post-treatment interviews. In the interviews, the students reported that before they attended the MetSI programme, they found maintaining concentration and remaining focused to be the most difficult obstacles to overcome when they listened to lectures delivered in English.

I always daydream during lectures, especially if it was boring or I couldn't hear the lecturer. (S2)

Concentrating was difficult . . . maybe I just daydreamt when I didn't understand ... (S3)

However, all ten students pointed out that the MetSI training had enabled them to be more focused during lectures and this had also helped them in maintaining their concentration. 
Before [the training] I just sit in the lectures . . now, I can concentrate better because I use the questioning strategy . . . the KWL sheet is also good [in maintaining concentration]. (S8)

I don't fall asleep in lectures now because I will take down notes using the KWL [sheet] or I use the questioning strategy ...

\section{Problem-Solving Strategies}

Problem solving is a method of enquiry. It is an important approach to find solutions to a problem. To assist students in becoming effective language learners, it is essential that their problem-solving abilities are enhanced. Although they were not aware of using problemsolving strategies, analysis of the questionnaire responses revealed that, prior to the treatment, the students did utilise problem-solving strategies in overcoming comprehension difficulties as they listened to lectures in English.

Pre-treatment questionnaire. The most used problem-solving strategy was using words that the students knew to guess the meaning of unknown words (85\%). Students also utilised their previous experience and knowledge to help them understand lectures $(83 \%)$ and used the general idea of the text to help them guess the meaning of words that they did not understand $(79 \%)$.

To assist with lecture comprehension, students also utilised other problem-solving strategies such as comparing what they understood with what they knew about the topic (79\%) and thinking about what they had learned before to check that they had guessed the meaning of a word correctly $(74 \%)$. However, the questionnaire findings also reveal that only a small majority of the students (58\%) adjusted their interpretation when they realised that they had guessed incorrectly.

Post-treatment interviews. The interviews revealed that one of the positive effects of the MetSI training was that it provided the students with more problem-solving options when they were faced with comprehension difficulties during lectures.

When I don't know the word the lecturer said, I try to think what the topic is about. (S1)

If the lecturer says something I don't know, I try to guess the meaning from what he said before. Sometimes I can understand it [when I use this strategy]. (S4)

\section{Discussion and Conclusion}

Listening is a demanding task and it is even more difficult to listen in a second language. Therefore, explicit strategy training such as the MetSI would assist ESL university students in developing their listening skills and improving their lecture-listening comprehension. Findings from the study show that prior to the strategy training, students faced difficulties in understanding university lectures delivered in English. They also faced challenges in maintaining concentration during lectures. In addition, there was a lack of awareness of strategies to improve their comprehension and strategies that could be utilised to help them extract information from lectures more effectively.

The problem was perhaps due to the fact that Malaysian schools do not explicitly teach students strategies on how to listen to long lectures. Hence, the people involved (lecturers, 
researchers, curriculum and material developers) should provide support for second language learners to facilitate the task of listening to lectures in English.

ESL professionals have an important role in assisting university students attending lectures in their second or foreign language. As these students face difficulties comprehending lectures in English, pre-sessional training or an in-session programme should be provided to the students. The training should prepare students with the language and listening skills that are required for students to effectively comprehend lectures. The training programme should emphasise exposing students to metacognitive strategies to maximise lecture comprehension.

Finally, more research needs to be conducted on the effects of metacognitive strategy training on students' lecture listening comprehension. It is hoped that through increasing students' metacognitive awareness, they will be able to play a more active role in overcoming their listening difficulties, rather than accepting that the difficulties are unavoidable.

\section{Author Note}

Suzanah Selamat, Faculty of Major Languages, Islamic Science University, Malaysia; Gurnam Kaur Sidhu, Faculty of Education, Universiti Teknologi MARA, Malaysia.

Correspondence concerning this article should be addressed to Suzanah Selamat, Faculty of Education, Universiti Teknologi MARA, Seksyen 17, 41000 Shah Alam, Selangor, Malaysia. Email: suzanah@usim.edu.my 


\section{References}

Anderson, A. \& Lynch, T. (1988). Listening. Oxford, England: Oxford University Press.

Aziz, R. A. \& Ismail, M. R. (2005). An analysis of problems in comprehending academic lectures. In K. Ariffin, M. R. Ismail, R. A. Aziz, M. Z. A. Latif, \& K. L. Ngo (Eds.), English in education: Issues and challenges in the Malaysian classroom (pp. 71-80). Shah Alam, Malaysia: Pusat Penerbitan Universiti, UiTM.

Benson, M. J. (1994). Lecture listening in an ethnographic perspective. In J. Flowerdew (Ed.), Academic English: Research perspectives (pp. 181-198). Cambridge, England: Cambridge University Press.

Buck, G. (1995). How to be a good listening teacher. In D. Mendelsohn \& J. Rubin (Eds.), A guide for the teaching of second language listening (pp. 59-73). San Diego, CA: Dominic Press.

Chamot, A. U. (1995). Learning strategies and listening comprehension. In D. Mendelsohn \& J. Rubin (Eds.), A guide for the teaching of second language listening (pp. 18-24). San Diego, CA: Dominic Press.

Cohen, A. D. \& Allison, K. C. (2000). Bilingual processing strategies in the social context of an undergraduate immersion program. In R. L. Cooper, E. Shohamy, \& J. Walters (Eds.), New perspectives and issues in educational language policy: In honour of Bernard Dov Spolsky (pp. 35-60). Amsterdam, The Netherlands: John Benjamins.

Coşkun, A. (2010). The effect of metacognitive strategy training on the listening performance of beginner students. Novitas-ROYAL (Research on Youth and Language), 4(1), 35-50.

Dunkel, P. A. (1991). Listening in the native and second/foreign language: Toward an integration of research and practice. TESOL Quarterly, 25(3), 431-457. http://dx.doi.org/10.2307/3586979

Dunkel, P. A., \& Davis, J. N. (1994). The effects of rhetorical signalling cues on the recall of English lecture information by speakers of English as a native or second language. In J. Flowerdew (Ed.), Academic listening: Research perspectives (pp. 55-74). Cambridge, England: Cambridge University Press.

Flowerdew, J. (Ed.). (1994). Academic listening: Research perspectives. Cambridge, England: Cambridge University Press.

Flowerdew, J., \& Miller, L. (1992). Student perceptions, problems and strategies in second language lecture comprehension. RELC Journal, 23(2), 60-79. http://dx.doi.org/10.1177/003368829202300205

Flowerdew, J., \& Miller, L. (2005). Second language listening: Theory and practice. Cambridge, England: Cambridge University Press.

Flowerdew, J., Miller, L., \& Li, D. C. S. (2000). Chinese lecturers' perceptions, problems and strategies in lecturing in English to Chinese-speaking students, RELC Journal, 31(1), 116138. http://dx.doi.org/10.1177/003368820003100106

Goh, C. (2000). A cognitive perspective on language learners' listening comprehension problem. System, 28(1), 55-75. http://dx.doi.org/10.1016/S0346-251X(99)00060-3

Goh, C. (2008). Metacognitive instruction for second language listening development: Theory, practice and research implications. RELC Journal, 39(2), 188-213. http://dx.doi.org/10.1177/0033688208092184

Hyon, J. J. (1997). A study of listening comprehension of academic lectures within the construction-integration model (Unpublished doctoral dissertation). The Ohio State University, Ohio, U.S.A.

Kaplan, S., \& Berman, M. G. (2010) Directed attention as a common resource for executive functioning and self-regulation. Perspectives on Psychological Science, 5(1), 43-57. http://dx.doi.org/10.1177/1745691609356784 
Long, M., \& Richards, J. (1994). Series editors' preface. In J. Flowerdew (Ed.), Academic listening: Research perspectives (pp. ix-x). Cambridge, England: Cambridge University Press.

Lynch, T. (1998). Theoretical perspectives on listening. Annual Review of Applied Linguistics, 18, 3-19. http://dx.doi.org/10.1017/S0267190500003457

Macaro, E., Graham, S., \& Vanderplank, R. (2007). A review of listening strategies: Focus on sources of knowledge and on success. In E. Macaro \& A. Cohen (Eds.), Language learner strategies: 30 years of research and practice (pp. 165-185). Oxford, England: Oxford University Press.

Mendelsohn, D. (1995). Applying learning strategies in the second/foreign language listening comprehension lesson. In D. Mendelsohn \& J. Rubin (Eds.), A guide for the teaching of second language listening (pp. 132-150). San Diego, CA: Dominic Press.

Mendelsohn, D. (1998). Teaching listening. Annual Review of Applied Linguistics, 18, 81-101. http://dx.doi.org/10.1017/S0267190500003494

Mendelsohn, D. (2002). The lecture buddy project: An experiment in EAP listening comprehension. TESL Canada Journal, 20(1), 64-73.

Morell, T. (2004). Interactive lecture discourse for EFL university students. English for Specific Purposes, 23(3), 325-338. http://dx.doi.org/10.1016/S0889-4906(03)00029-2

Ogle, D. M. (1986). K-W-L: A teaching model that develops active reading of expository text. Reading Teacher, 39(6), 564-570. http://dx.doi.org/10.1598/RT.39.6.11

O'Malley, J. M., \& Chamot, A. U. (1990). Learning strategies in second language acquisition. Cambridge, England: Cambridge University Press.

Oxford, R. L. (1990). Language learning strategies: What every teacher should know. Boston, MA: Heinle \& Heinle.

Oxford, R. L. (1993). Research update on teaching L2 listening. System, 21(2), 205-211. http://dx.doi.org/10.1016/0346-251X(93)90042-F

Oxford, R. L. (Ed.). (1996). Language learning strategies around the world: Cross-cultural perspectives. Manoa, HI: University of Hawaii Press.

Richards, J. C. (1983). Listening comprehension: Approach, design, procedure. TESOL Quarterly, 17(2), 219-240. http://dx.doi.org/10.2307/3586651

Rost, M. (1994). On-line summaries as representations of lecture understanding. In J. Flowerdew (Ed.), Academic listening: Research perspectives (pp. 93-127). Cambridge, England: Cambridge University Press.

Rubin, J. (1994). A review of second language listening comprehension research. The Modern Language Journal, 78(2), 199-221. http://dx.doi.org/10.2307/329010

Swan, M. (2011). Using texts constructively: What are texts for? Retrieved from http://www.teachingenglish.org.uk/articles/using-texts-constructively-what-are-texts

Vandergrift, L. (2002). 'It was nice to see that our predictions were right': Developing metacognition in L2 listening comprehension. Canadian Modern Language Review, 58(4), 555-575. http://dx.doi.org/10.3138/cmlr.58.4.555

Vandergrift, L. (2003). From prediction through reflection: Guiding students through the process of L2 listening. Canadian Modern Language Review, 59(3), 425-440. http://dx.doi.org/10.3138/cmlr.59.3.425

Vandergrift, L. (2004). Listening to learn or learning to listen? Annual Review of Applied Linguistics, 24, 3-25. http://dx.doi.org/10.1017/S0267190504000017

Vandergrift, L., Goh, C. C. M., Mareschal, C. J., \& Tafaghodtari, M. H. (2006). The metacognitive awareness listening questionnaire: Development and validation. Language Learning, 56(3), 431-462. http://dx.doi.org/10.1111/j.14679922.2006.00373.x 
Wenden, A. (1985). Facilitating learning competence: Perspectives on an expanded role for second-language teachers. Canadian Modern Language Review, 41(6), 981-990.

Wenden, A. (1998). Metacognitive knowledge and language learning. Applied Linguistics, 19(4), 515-537. http://dx.doi.org/10.1093/applin/19.4.515 


\section{Appendix A \\ Post-Treatment Interview}

Student Name:

B.Ed Programme:

Warm-up

- Greet the student and ask permission to tape the conversation.

- Explain the reason for the interview: to know the student's opinion about the MetSI programme.

Questions

1. How would you describe the level of your understanding of lectures before the MetSI programme? Were the lectures difficult / easy? Why? How would you describe the level of your understanding of lectures after the MetSI programme?

2. Before the programme, when you were listening to a lecture, what factors influenced your understanding?

3. Why do you think they influenced your understanding?

4. Now, after the programme, what factors influence your understanding?

5. What did you usually do to understand lectures before, during, and after listening to lectures before attending the MetSI programme? Since completing the MetSI programme, what do you usually do?

6. Describe your MetSI training experience.

What changes did you experience through attending the MetSI programme?

Which strategies did you like / dislike? Why?

7. Do you think the programme was beneficial to you?

Why / why not?

Appendix B

KWL Chart

\begin{tabular}{|c|c|c|}
\hline K & W & L \\
What I KNOW & What I WANT to know & What I LEARNED \\
\hline & & \\
& & \\
\hline
\end{tabular}

(adapted from Ogle, 1986) 


\section{Appendix C \\ Metacognitive Listening Sequence Instructor's Guide}

1. Prior to the first listening, ask students to state what their goals are.

2. Put students in pairs.

3. Ask them to discuss what they know about the topic and predict the information and words that they might hear.

4. Ask students to predict problems they might encounter and think how they would overcome these problems.

5. Let students listen to the text and tell them to underline words that they predicted correctly while listening. Also ask them to jot down new words or information as they listen.

6. Ask students to compare what they have understood so far and describe strategies that they have used to help them with their understanding.

7. Tell students to note down problems or disagreements that they have with their partners.

8. Demonstrate (through thinking aloud) how to listen selectively to the problematic parts of the listening text.

9. Play the text again. As students listen again to the text, ask them to make notes on any new information they hear.

10. Finally, discuss findings with the whole class.

(adapted from Vandergrift, 2003) 